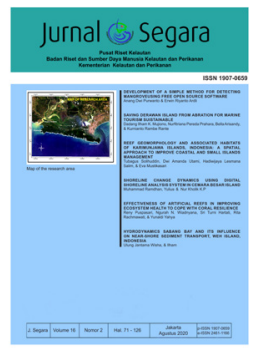

JURNAL SEGARA

http://ejournal-balitbang.kkp.go.id/index.php/segara

ISSN : 1907-0659

e-ISSN : 2461-1166

Nomor Akreditasi: 766/AU3/P2MI-LIPI/10/2016

\title{
SHORELINE CHANGE DYNAMICS USING DIGITAL SHORELINE ANALYSIS SYSTEM IN CEMARA BESAR ISLAND
}

\section{DINAMIKA PERUBAHAN GARIS PANTAI MENGGUNAKAN SISTEM ANALISIS GARIS PANTAI SECARA DIGITAL DI PULAU CEMARA BESAR}

\author{
Muhammad Ramdhan'1), Yulius'1), \& Nur Kholik K P2) \\ 1) Researcher in Marine Research Center, BRSDM - KKP \\ ${ }^{2)}$ Oseanography Student in Diponegoro University, Semarang \\ JIn. Pasir Putih 1 Ancol Jakarta; Telp/fax: +62 2164711583
}

Received: 23 December 2019; Revised: 22 Juni 2020; Accepted: 30 July 2020

\begin{abstract}
This paper will describe a study to find out the shoreline changes that occurred on Cemara Besar Island along with the accretion and abrasion. Data taken from the images were obtained through google earth as a result of radiometry and geometry correction from Landsat satellites in the last of 5 years. Wind data were obtained from ECMWF (European Centre for Medium-range Weather Forecasts) interm every season for 5 years. Analysis of shoreline changes was carried out using the DSAS (Digital Shoreline Analysis SYSTEM) method and analyzed by wind and sea wave factors involved in each season. The results of the analysis obtained LRR (Linear Regration Rate) and EPR (End Point Rate) values for 5 years, the extent of changes in island land mass, the value of $\mathrm{Hs}$ and Ts from the results of wave forecasting using wind data. To simplify the analysis, Cemara Besar Island is divided into 9 segments based on variations in LRR values. The results show that in general Cemara Besar Island have very high accretion rate in segments A, B and E with an average of $3.61 \mathrm{~m} /$ year or 5 years and very high abrasion occurred in segment $F$ with an average of $-1.01 \mathrm{~m}$. Abrasion occurs with the greatest speed of change in segment A with an average of $4.64 \mathrm{~m} /$ year and the largest accretion rate in segment $F$ with an average of $-1.21791 \mathrm{~m} /$ year. Analysis of oceanographic factors through Wave forecasting data shows that in the west and transition I season, the significant waves height occur with $\mathrm{Hs} 1.21 \mathrm{~m}$, greater than the eastern season and transition II season with $\mathrm{Hs} 0.91 \mathrm{~m}$. Dominant wind direction from north (377.50 in west season and transition I, and from east direction (67,25 degre) in east season and transition I season. Wind-wave propagate according to wind direction and it will be deformed when entering shallow coastal waters. Then affects sediment transport which produces accretion and abrasion on the Cemara Besar Island.
\end{abstract}

Keywords: DSAS, Shoreline dynamics, Cemara Besar Island.

\section{ABSTRAK}

Makalah ini memaparkan suatu studi untuk mengetahui perubahan garis pantai yang terjadi di Pulau Cemara Besar beserta akresi dan abrasi tersebut. Data yang bersumber dari Google Earth yang telah dikoreksi secara radiometri dan geometri dari citra satelit Landsat dalam 5 tahun terakhir. Data angin diperoleh dari ECMWF (European Center for Medium-range Weather Forecasts) interm setiap musim selama 5 tahun. Analisis perubahan garis pantai dilakukan dengan metode DSAS (Digital Shoreline Analysis System) dan dianalisis dengan faktor angin dan gelombang laut yang terlibat di setiap musim. Hasil analisis diperoleh nilai LRR (Linear Regration Rate) dan EPR (End Point Rate) selama 5 tahun, Iuasnya perubahan massa daratan pulau, nilai Hs dan Ts dari hasil peramalan gelombang menggunakan data angin. Untuk mempermudah analisis, Pulau Cemara Besar dibagi menjadi 9 segmen berdasarkan variasi nilai LRR. Hasil penelitian menunjukkan bahwa secara umum Pulau Cemara Besar memiliki laju akresi yang sangat tinggi pada segmen A, B dan E dengan rata-rata 3,61 m / tahun atau 5 tahun dan abrasi sangat tinggi terjadi pada segmen F dengan rata-rata -1,01 m. Abrasi terjadi dengan kecepatan perubahan terbesar pada segmen A dengan rata-rata 4,64 m / tahun dan laju akresi terbesar pada segmen $F$ dengan rata-rata -1,21791 $m$ / tahun. Analisis faktor oseanografi melalui data prakiraan gelombang menunjukkan bahwa pada musim barat dan transisi I tinggi gelombang signifikan terjadi dengan Hs 1,21 m, lebih besar dari musim timur dan musim transisi II dengan Hs 0,91

Corresponding author:

Jl. Pasir Putih I Ancol Timur, Jakarta Utara 14430. Email: m.ramdhan@kkp.go,id 


\begin{abstract}
m. Arah angin dominan dari utara (377,50 derajat pada musim barat dan transisi l, dan dari arah timur (67,25 derajat) pada musim timur dan musim transisi I. Gelombang angin merambat sesuai arah angin dan akan berubah bentuk saat memasuki perairan pantai dangkal Kemudian mempengaruhi transpor sedimen yang menghasilkan akresi dan abrasi di Pulau Cemara Besar.
\end{abstract}

Kata kunci: DSAS, Dinamika Garis Pantai, Pulau Cemara Besar.

\section{INTRODUCTION}

The beach is a complex ecosystem. Its complexity is characterized by natural and non-biological natural resources (Beatley et al., 2002, Aedla et al., 2015). From the perspective of interaction, the beach becomes a zone of interaction between land, sea, and air which has the ability to adjust to maintain natural balance. The ability of the coast to respond to the dynamics process of oceanographic causes the coast to be a dynamic area (Triatmodjo, 1999, Hidayat, 2012). Beaches consist of many natural process dynamics that occur, both from sea to land and vice versa. Some natural processes that occur such as abrasion, accretion, sediment transport pollution, and environmental pollution. While the processes formed due to human activities such as the process of development and management of coastal areas. Changes in beach profile occurred depending on the beach topography, hydro-oceanographic processes, climatic conditions, coastal vegetation, and sediment transport that occurs (Triatmodjo, 1999, CERC, 1984, Guariglia et al., 2006).

Beaches are included in coastal areas that are still influenced by tidal phenomena. The beach has the ability to absorb ocean wave energy that radiates to the coast. Beach functions as a buffer can protect sea cliffs, settlements on the coast. Wave propagation carries sediment intake within a certain period of time. This process causes pressure on the coastal area, which is usually characterized by the presence of abrasion and accretion on a beach (Febriansyah et al., 2012 ;Siswanto et al., 2012) .

The coastline is defined as the location of a meeting between land and sea which has high dynamics of natural processes. The shape and location of the coastline can constantly change based on conditions between land and sea over a period of time (Guariglia et al., 2006, Alesheikh et al., 2007, Tran \& Trinh, 2009). Factors in geological strength and extreme phenomena can have an impact on shoreline changes (Addo et al., 2011, Boak \& Turner, 2005).

One form of wave deformation when entering the shore is a refractive angle of the wave, which is formed between the waves crest and coastline. The resultante of the zig-zag movement of the wave refraction process produces the longshore current. Suspended sediment due to breaking waves carried away by the Longshore current, this process is known as longshore drift. Components of the wave that affect them include the coming angle, duration, and wave energy, where wave energy is proportional to the wave height (Triatmodjo, 1999, Hidayat et al., 2013).

The large pine island has a fairly wide sand area (Hartati \& Ambariyanto, 2005). Plains of the island are overgrown with pine trees with little mangrove. Sediment cover on the majority island of gravel mud with distribution to Karimun Island and Menjangan Island. Furthermore sediment in the form of alluvium is typically composed of crust, gravel, sand, clay, coral fragments, and pumice (Gustiantini \& llahude, 2016).

Cemara Island is a large island under the authority of the use and management of the Ministry of Maritime Affairs and Fisheries. While the waters of the Big Pine Island are included in the management area of Karimun Jawa National Park (Umardiono, 2011). Further explained that one component of tourism development is geographical conditions including geology, topography, and seasons. Likewise, geographical conditions are a factor in the evaluation of tourism resources. Thus, the phenomenon of shoreline change needs to be identified. The importance of this is that tourism areas require physical needs such as infrastructure that need comprehensive spatial planning.

So as a contribution effort in the arrangement of coastal spaces, and small islands, this study was carried out to see the changes in the coastline that occurred during the period 2013 - 2018 and to find out the level of abrasion and accretion that occurred. In addition, this study also aimed to see the extent of land changes the island caused by abrasion and accretion. Thus it can be analyzed the causes and chronology of the emergence of abrasion and accretion along the coast of the Cemara Besar Island.

\section{METHODOLOGY}

The study was carried out on the Big Cemara Island which is included in the Karimun Jawa Islands, Jepara Regency. The study area of shoreline change is at $110.383087^{\circ} \mathrm{E}-110.365044^{\circ} \mathrm{E}$ and $5.801994^{\circ} \mathrm{S}$ $5.811045^{\circ} \mathrm{S}$. Analysis of shoreline changes in this study was related to sea wave conditions in the waters around Cemara Besar Island as shown in Figure 1 flowchart. Satellite data and wind data temporal range 
was 5 years $(2013-2015)$.

\section{Shoreline changes}

The satellite image used on this study is Landsat imagery produced by Google Earth Pro with the acquisition date of March 13, 2013, October 29, 2016 , and February 21, 2018. The image of Google Earth Pro was chosen because it contain a Landsat imagery and other multi spatial resolution satellite imagery. Landsat has advantages to cover a wide geographical area and has several bands with spectrum values that are suitable for analysis of shoreline changes (Miller et al., 2011). The selection of the acquisition date is based on tidal calculations with reference to the water level which is the same as the Mean High Water Level (MHWL).

Coastline information is obtained by delineation carried out on-screen digitized considering the narrow location of the digitized research is done by identifying differences in line boundaries between dry and wet areas (Esmail et al., 2019, G et al., 2019). Analysis of changes in area was carried out overlaying island mainland polygons from all years. This method is done to find out the extent of differences that are different from abrasion and accretion (Ozturk \& Sesli, 2015). Whereas to find out the level of abrasion and accretion transects that are perpendicular to the deepest coastline are used using the Digital Shoreline Analysis System (DSAS) method (Esmail et al., 2019; Gibson 2006; Salmon et al., 2019).

The calculation on DSAS is based on the distance between the baseline and the entire coastline. DSAS consists of several transects that can be determined according to the beach conditions. DSAS automatically calculates statistical data for Shoreline Change Envelope (SCE), Net Shoreline Movement (NSM), End Point Rate (EPR), Linear Regression Rate (LRR), Weighted Linear regression (WLR), and Least Median of Squares (LMS). This study uses statistical data used, namely NSM, EPR, and LRR with 1 meter transect distance and 120 meters transect distance. Data on EPR and LRR are then classified into 4 classes for

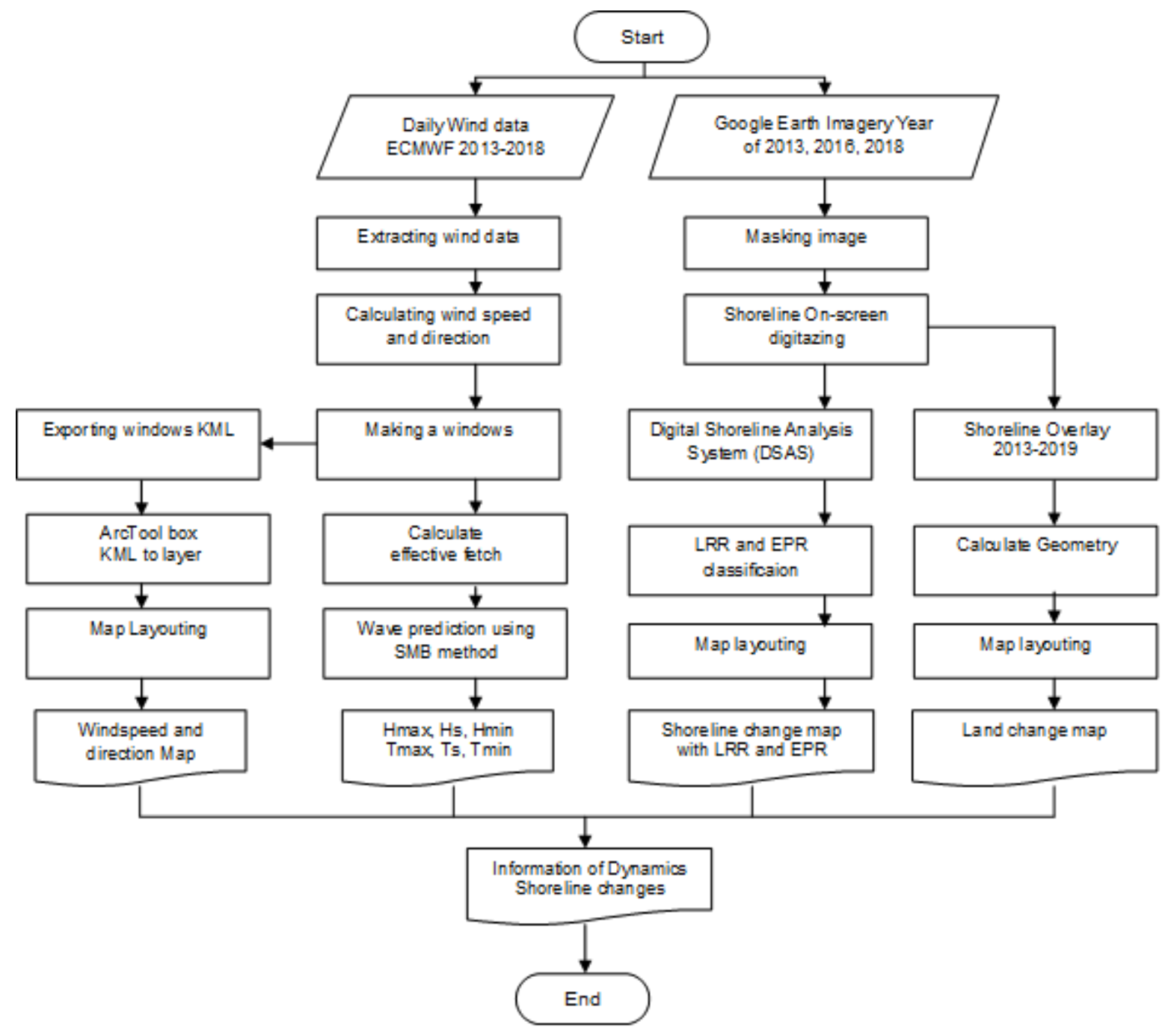

Figure 1. Flowchart of the study. 
abrasion and accretion respectively. Calculation of classification is based on standard deviation and average of LRR and EPR.

The statistical results and classification of EPR and LRR values are displayed in maps prepared using ArcGIS 10.5 software. While NSM data is used to see the distance of accretion and abrasion changes that occur along the transect.

\section{Wave Generation}

Daily speed and wind direction data are obtained from the ECMWF website. Wind direction and velocity data that have been obtained is used for wave forecasting using the SMB (Svedrup-MunkBretschneider) method referring to CERC, 1984. Stages of ocean wave forecasting consist of wind data filtering, determination of effective fetch length, calculation of period and height of ocean waves. Data is carried out until the height and wave period are obtained according to the equation expressed in:

$$
\frac{g H_{1 / 3}}{U_{10}^{2}}=0.26 \tanh \left[\left(\frac{1}{f_{m} U_{10}}\right)^{3 / 2} \frac{(3.5 g)^{3 / 2}}{10^{2}}\right]
$$

where $\mathrm{H} 1$ / 3 or $\mathrm{Hs}$ : significant wave height $33.3 \%$ of wave population, U10: wind speed at an altitude of 10 meters above sea level $(\mathrm{m} / \mathrm{s})$, fm: peak frequency in the wave spectrum. However, fm cannot be determined, but is derived from the inverse count of significant $\mathrm{H}$.

Wind data is at an altitude of 10 meters, so it needs to be corrected by correcting the equation (Resio et al., 2003)

$$
U_{z}=U_{10}\left(\frac{z}{10}\right)^{\alpha}
$$

where $U_{z}$ : wind speed is measured from the height of the station location $(\mathrm{m} / \mathrm{s}), U_{10}$ : wind speed at an altitude of 10 meters (m.s), and $z$ is the height of the surface $(\mathrm{m})$, and $\alpha$ : power index of 0.12 .

Wind data used is consists of wind data on March, June, September and December which are expected to represent 4 seasons in Indonesia namely West Season, Transition Season 1, East Season and Transition Season II (Hutabarat \& Evans, 1985). Determining the point of wind location is based on the location of the closest sample point to the Cemara Besar Island, which is at $110.3750^{\circ} \mathrm{E} ; 5.8750^{\circ} \mathrm{S}$.

Determination of effective length fetch is based on the dominant direction of wind blowing on all four seasons. Then a straight line is drawn for a maximum of $200 \mathrm{~km}$. When crashing into an island or land, the fetch length is stopped to land/island. The fetch line is made of 15 lines as wide as 840 every 60 both positive and negative sides directions from the dominant wind direction. So that there will be length of fetch effective for one season through the equations used by Resio, (Bratos \& Thompson, 2003; Etemad-Shahidi et al., 2009) :

$$
X=\frac{\sum_{i=1}^{15} X_{i} \cos \alpha_{i}}{\sum_{i=1}^{15} \cos \alpha_{i}}
$$

where $X$ : effective fetch length $(m), \alpha$ : angle from the dominant direction (multiples of 60).

Hs height can be determined if it is in fetch-limited condition. This condition if duration llimited is greater than Tmin. Then the equation used to get is written in (CERC, 1984) :

$$
\frac{g H_{g}}{U^{2}}=0.283 \tanh \left[0.0125\left(\frac{g X}{U^{2}}\right)^{0.42}\right]
$$

where Hs: significant wave height $(\mathrm{m}), \mathrm{U}$ : corrected wind speed $(\mathrm{m} / \mathrm{s})$, and g: gravitational acceleration $\left(9.81 \mathrm{~m} / \mathrm{s}^{2}\right)$.

\section{RESULTS AND DISCUSSION}

\section{Area Changes}

Analysis of the land change was done to see coastal changes within a certain period of time. The result shows a change in the coastline of Cemara Besar Island on Figure 2. Changing coastlines occurred massively in the period of 2013 - 2016 (Table 1). Accretion occurred on the period of 2013 - 2016 is characterized by the presence of new land in segments A and B (Figure 3). Whereas changes from 2016 - 2018 appear to be only the movement of sediments from one place to another. From the map (Figure 3) it can be traced to the phenomenon of abrasion-accretion that occurs along the coast of Cemara Besar Island.

The first review, 2013 was the land of light brown, then experienced abrasion in the period of 20132016 covering an area of $1,230 \mathrm{~m}^{2}$. The abrasion that

Table 1 Abrasion-accretion Areas in
Cemara Besar Island

\begin{tabular}{ll}
\hline Condition & Area $\left(\mathbf{m}^{2}\right)$ \\
\hline Accretion 2016 - 2018 & 3954.219 \\
Abbration 2016 - 2018 & 3229.613 \\
Accretion 2013-2016 & 6226.484 \\
Abbration 2013-2016 & 1230.000 \\
\hline
\end{tabular}




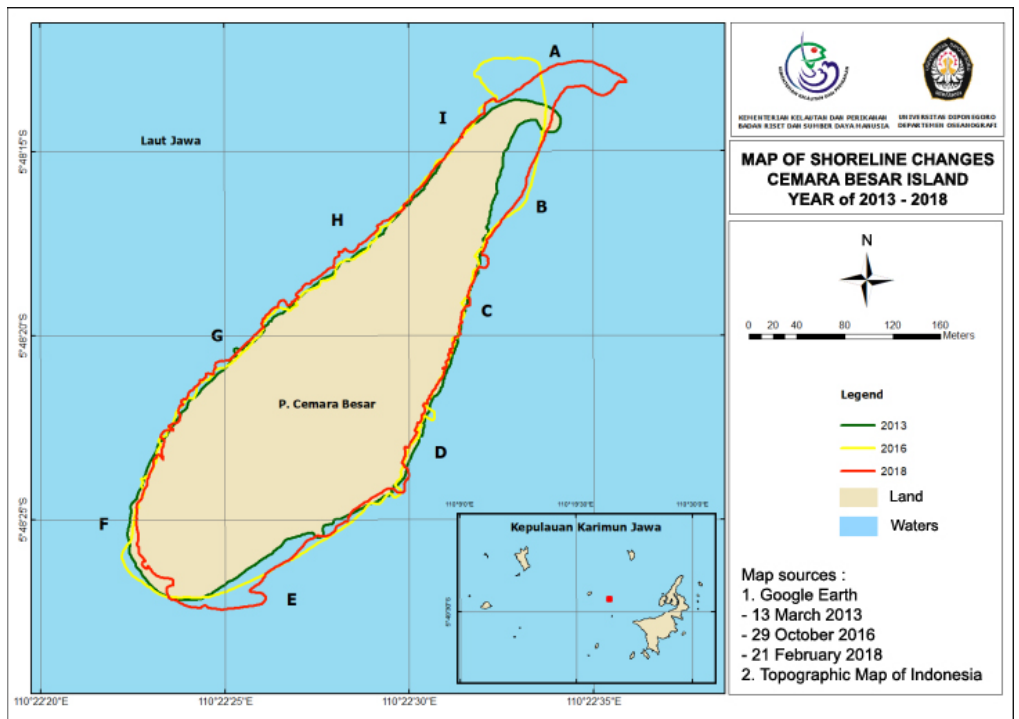

Figure 2. Shorelines Changes in Cemara Besar Island in 2013 - 2108.
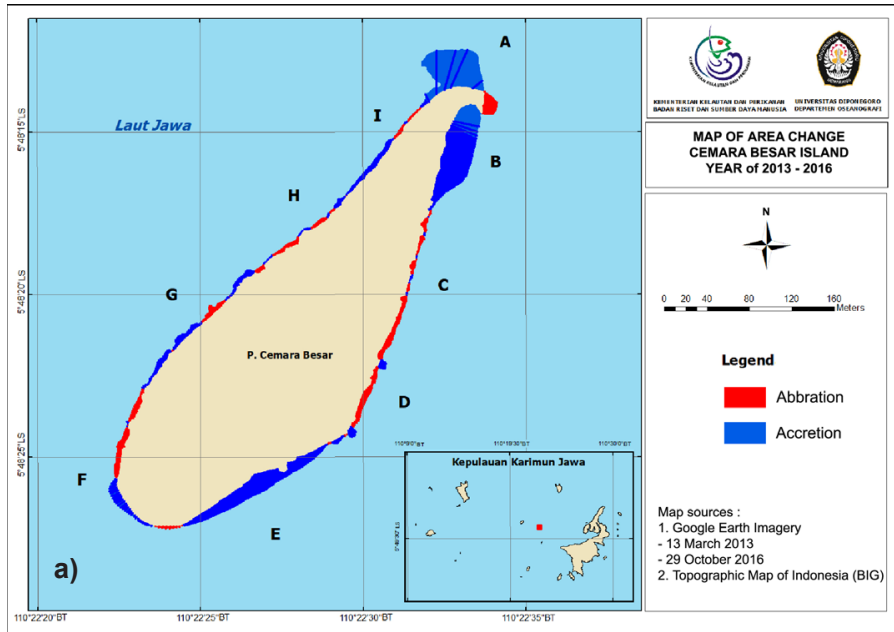

Figure 3.

occurred is small, it appears abrasion in the B, C, D, $\mathrm{F}, \mathrm{G}$ and $\mathrm{H}$. which segments are in the same period the big Cemara Island is like getting a lot of sediment supply, The land arises in the same period, so that new land formed through accretion from 2013 to 2016 is marked with green with area of 6,226,484 $\mathrm{m} 2$. This new land in the next period was abrased and moved to land in blue. This braking occurred in the period 2016 - 2018 covering an area of $322,613 \mathrm{~m}^{2}$. The length of the braking occurred in segment $F$. The $2016-2018$ accretion sediment supply was thought to originate from the mainland. It will have an impact on the ecosystem, and spatial planning.

\section{Abbration and Accretion}

Abrasion and accretion along the coast of Cemara Island are classified into 8 classes. Basic classification is based on standard deviation values with a middle value of 0 , and abrasion ranges if $>0$ and accretion < 0 . The DSAS analysis shows a variety of abrasion and accretion levels in each segment.

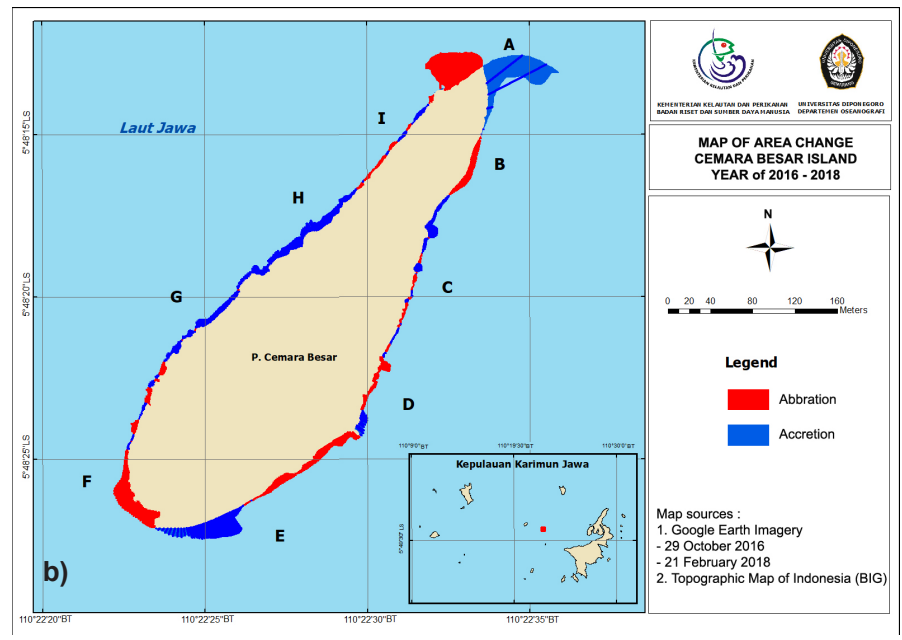

a) 2013 - 2016; b) 2016 - 2018 .

Based on Figure 4, the LRR parameter shows that very high abrasion occurred in the $F$ segment marked with bright red. Whereas moderate to weak abrasion is in segments $D$ and $C$. The same condition is shown by the EPR parameter that in segments $F, D$ and $\mathrm{C}$ shows the existence of abrasion. The red the color of the transect, the smaller the EPR means the speed of the abrasion rate in meters/year is getting bigger.

The abrasion range is shown in Figure 2 that at $F$ segment maximum LRR and EPR values are in the abrasion category. So that the average value of the $F$ segment is accretion at -1.006 for LRR and $-1.218 \mathrm{~m} /$ year for EPR. While segments $D$ and $C$ the maximum value is in the accretion category, but the average value indicates abrasion. In segment $D$ there was an abrasion with an average of -0.663 for LRR and -0.750 myear for EPR, while segment $C$ with a narrower range had an abrasion average of -0.281 for LRR and -0.216 $\mathrm{m} /$ year for EPR. 

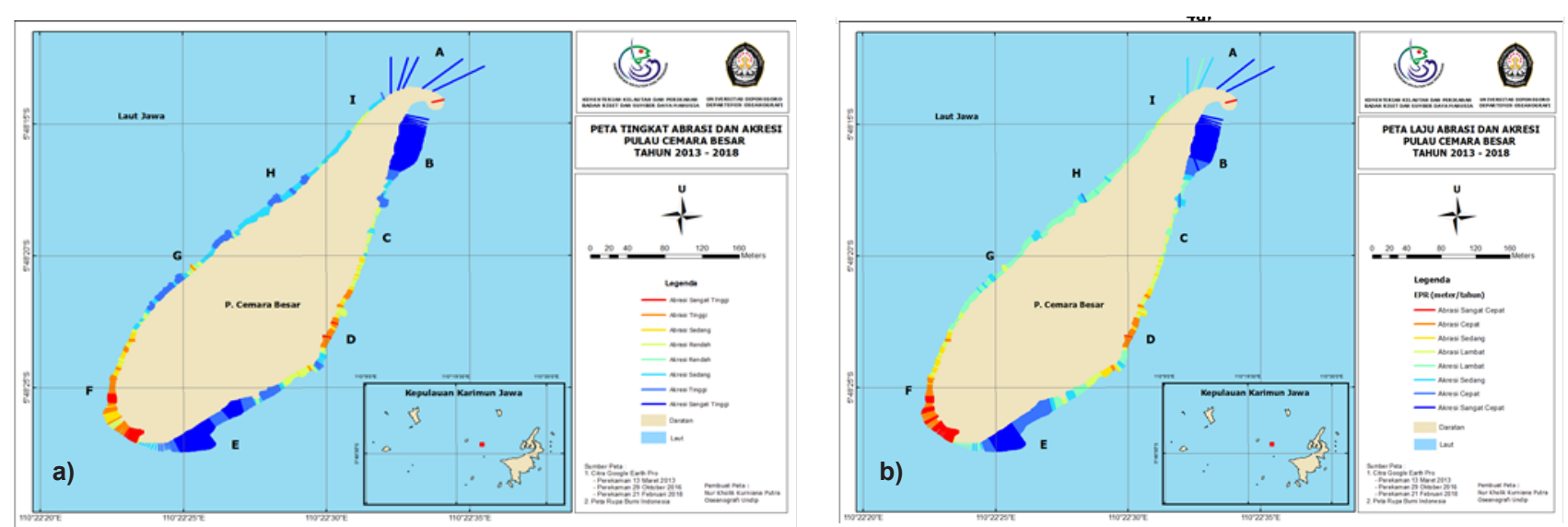

Figure $4 . \quad$ a) Abbration and Accretion Value; b) Abbration and Accretion Rates.

The abrasion phenomenon will be followed by accretion on the other parts of the beach, according to the principle of natural balance. The opposite is also true, meaning that abrasion and accretion are interrelated process dynamics in the process of natural balancing (Boak \& Turner 2005).

The accretion process is more dominant than abrasion along the coast of Cemara Island. In terms of Figure 1, the positive average values for LRR and EPR are 6 segments, namely: segments A, B, E, G, $\mathrm{H}, \mathrm{I}$. The highest accretion is in segment $A$ with an average value of 4,644 m / year for EPR and 4,931 for LRR. While the lowest accretion is in segment I with an average value of $0.290 \mathrm{~m} / \mathrm{year}$ for EPR and 0.322 for LRR.

Based on Figure 4a) very high accretion occurs in segments $A, B$ and $E$. While segments $G, H$, I experience moderate to weak accretion, with several high locations. However, different things shown in Figure 4b) based on EPR parameters show very [high or low?] accretion rates. height remains in segments $A$, $B$ and $E$. while segments $G, H$, I have accretion rates that tend to be slow.

Accretion and abrasion on the coast have uniformity along the west coast, and uniformity on the east coast. The west coast has a tendency to lower accretion rates with high abrasion rates. While on the east coast the accretion rate is very high with a low abrasion rate. this needs to be reviewed fromthe hydrooceanographic aspects that work along the coast.

\section{Sea Wave}

The condition of the sea waves that spread along the coast of Cemara Island is influenced by the wind. Wind conditions throughout 2013 - 2018 experience differences in direction and speed in each season such as. Based on, it has the same dominant direction for the western season and transition I, which is blowing from 337.50 , which is northward towards the northwest. Whereas for the eastern season and transition II blowing from the direction of 67,250 which is the northeasteast direction. The difference in wind direction in each season causes differences in the wave conditions that are generated.

Based on wave forecasting using the SMB method, it is obtained high $\mathrm{Hs}$ and Ts periods for each season. Judging from shows that the height and wave period in the western season and transition I tend to be higher than the east and transition II.
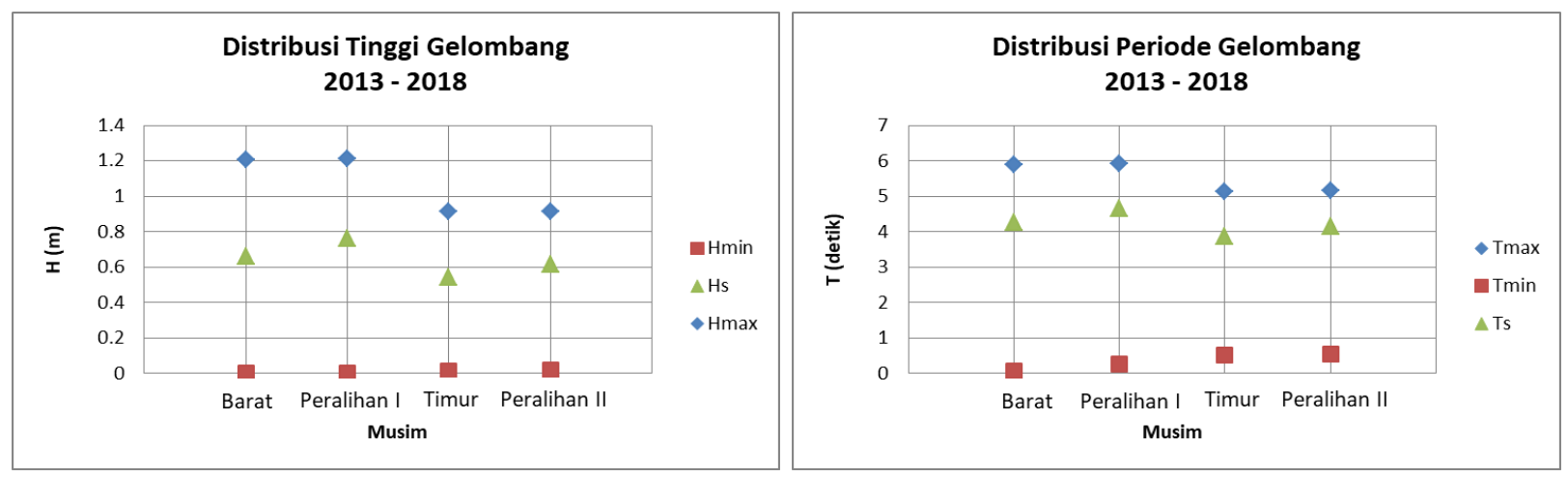

Figure 5. a) Distribution of Wave Height $\mathrm{H}(\mathrm{m})$; b) Distribution of Wave Period $\mathrm{T}$ (second). 
Judging from the high distribution of $\mathrm{Hs}$ and the dominant direction of the wind, the large waves occur in the western season and the transition season I with propagation from the direction of 377.50 . So that the west coast is directly affected by this large wave. transition I with relatively low $\mathrm{Hs}$ with the dominant direction of 67,250 . This condition can show if the difference in accretion rates between the east and west coasts is due to differences in waves leading to the coast.

\section{Sediment Rate}

Sediment supply can be reviewed with 3 methods, namely measuring direct sediment discharge, image analysis, and using empirical formulas for sediment (Triatmodjo, 1999). Based on descriptive analysis based on the empirical formula proposed by ljima and Tang, 1967 as follows (ljima \& Tang, 1967):

$$
\begin{aligned}
& \mathrm{Po}=0.09952 \mathrm{n} \rho \mathrm{H}^{2} \mathrm{~T} \operatorname{Sin} \varnothing \\
& \mathrm{P}_{1}=0,5 \mathrm{Po} \operatorname{Sin} 2 \varnothing \\
& \mathrm{Q}=\mathrm{KP}_{1} /\left(\rho_{j}-\rho\right) \mathrm{g}(1-\mathrm{p})
\end{aligned}
$$

With Po is the energy of wave flux (newton-meter / second), H: wave height (m), T: wave height (s), ø: wave coming angle, and $\rho$ : water density of $1025 \mathrm{~kg} / \mathrm{m}^{3}$. That the height and wave period are directly proportional to the energy of the wave flux found on the beach. Energy wave fluxes state the amount of energy received by the coast based on the incoming wave. Flux energy waves are also directly proportional to the rate of $Q$ sediment volume ( $\left.\mathrm{m}^{3} / \mathrm{day}\right)$. So that in this case, the height and wave period of the wave forecasting results can explain the differentiation in the conditions of the sediment volume rate between the west coast and the east coast of the Cemara Besar Island.

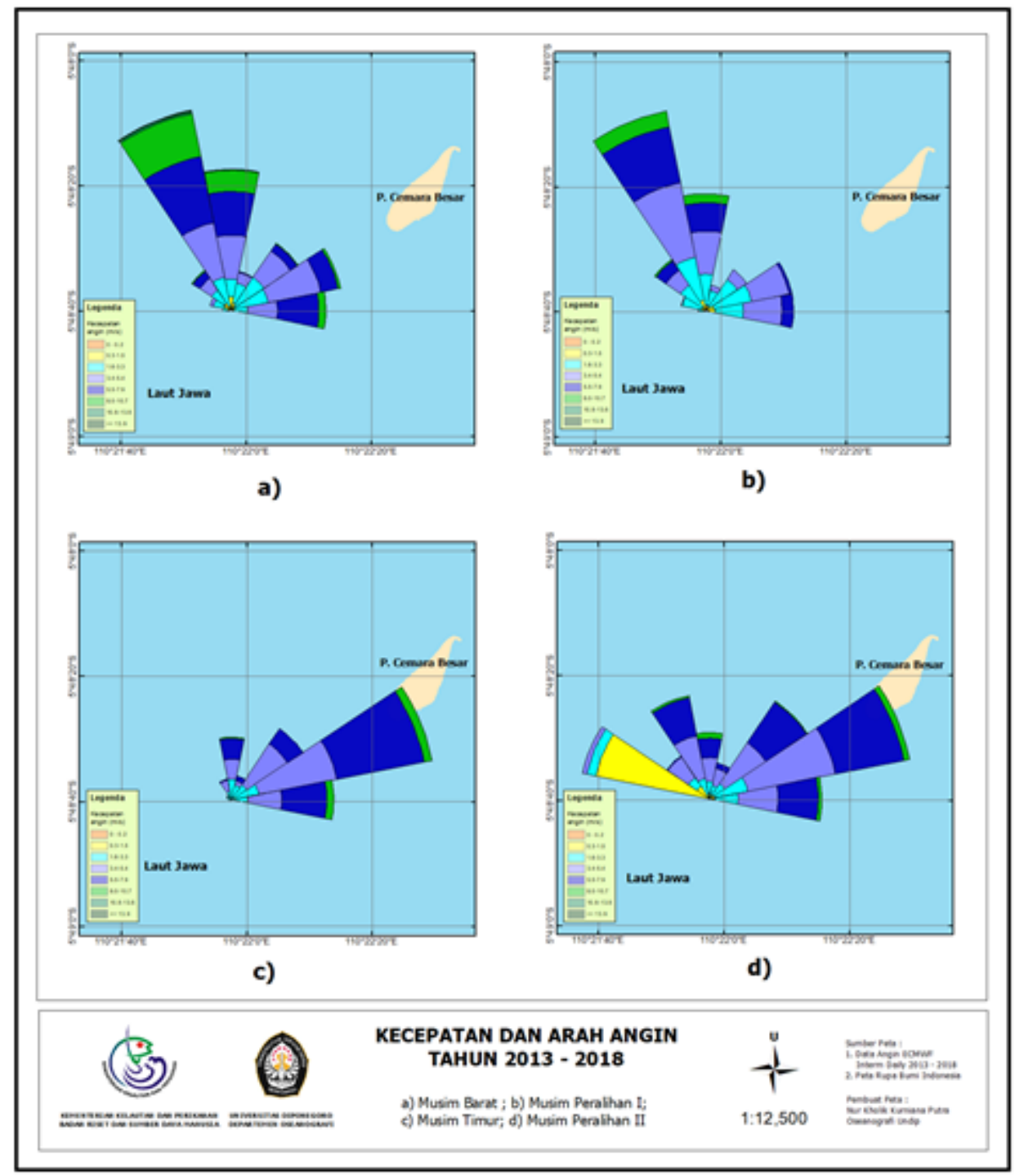

Figure 6. Speed and direction of the Wind in all season. 
Viewed in Figure 4a shows that in segment $\mathrm{F}$ there is very high abrasion. This can be caused by large flux energy, especially during the western season and transition I. Sediment in the $F$ segment moves to segment $E$ and along $G, H$, I. However, it is not known for sure the sediment supply in segments $\mathrm{G}, \mathrm{H}$, I originates from segment $F$.

Different conditions occur on the east coast. As shown in Figure $4 a$ that the east side coast experiences very high accretion in segments $A, B$, and $E$. This accretion can occur due to the relationship of sediment transport between the surrounding islands. It is marked by distance and connectivity between the islands. The Big Pine Island is closer to Karimun in the east which is actually a large island. This connectivity can answer the accretion level on the east side which is very high, as long as the sediment supply originates from Karimun Island at a rate that effective during the east and transition seasons II. This is in accordance with Gustiantini \& Ilahude (2016) in the map presented illustration if Cemara Besar Island has the same sediment distribution as Karimun Island, which is muddy mud.

\section{CONCLUSION}

Analysis using the Digital Shoreline Analysis System was able to show the presence of abrasion and accretion along the coast of Cemara Besar Island from the changes in coastline that occurred. Changes in the island's largest land area in $2013-2016$ due to accretion of $6226,483 \mathrm{~m}^{2}$. The accretion rate is very high in segments $A, B$, and $E$ as well as very high abrasion in segment $F$. The accretion and abrasion phenomena are approached by the empirical formula of the volume of sediment, that accretion and abrasion are influenced by waves with different characteristics each season and similarity of sediments with nearest island island.

This study has disadvantages in terms of verification of field data. Thus, it would be better if the coastline was verified with field data. In addition, an analysis of the sediment supply rate can be carried out directly either by measuring sediment discharge or by empirical formula with direct observation of the incoming wave and verification of wave forecasting data.

\section{ACKOWLEDGEMENTS}

All authors have the same contribution in writing this paper. Authors wishing to acknowledge assistance and encouragement from all colleagues, special work by technical staff and financial support from Ministry of marine and fisheries, Republic of Indonesia.Also, the support from Dipenogoro University.

\section{REFFERENCE}

Addo, K.A., Jayson-Quashigah, P.N., \& Kufogbe, K.S. (2011). Quantitative analysis of shoreline change using medium resolution satellite imagery in Keta, Ghana, Marine Science, 1(1), 1-9.

Aedla, R., Dwarakish, G.S., \& Reddy, D.V. (2015). Automatic Shoreline Detection and Change Detection Analysis of Netravati-GurpurRivermouth Using Histogram Equalization and Adaptive Thresholding Techniques, Aquatic Procedia, 4, pp. 563-570. doi: https://doi.org/10.1016/j. aqpro.2015.02.073.

Alesheikh, A.A., Ghorbanali, A., \& Nouri, N. (2007) 'Coastline change detection using remote sensing', International Journal of Environmental Science \& Technology. Springer, 4(1), 61-66.

Beatley, T., Brower, D., \& Schwab, A.K. (2002). An introduction to coastal zone management. Island Press.

Boak, E.H., \& Turner, I.L. (2005). Shoreline definition and detection: a review, Journal of coastal research, pp. 688-703.

CERC, S.P.M. (1984). Coastal Eng. Research Centre', US Army Corps of Eng., Washington.

Esmail, M., Mahmod, W.E., \& Fath, H. (2019) Assessment and prediction of shoreline change using multi-temporal satellite images and statistics: Case study of Damietta coast, Egypt', Applied Ocean Research, 82, 274-282. doi: https://doi.org/10.1016/j.apor.2018.11.009.

Etemad-Shahidi, A., Kazeminezhad, M.H. \& Mousavi, S.J. (2009). On the prediction of wave parameters using simplified methods, Journal of Coastal Research. JSTOR, 1, 505-509.

Febriansyah, I., Nugroho, D.S.A., \& Helmi, M. (2012, in Indonesia). Coastal vulnerability assessment on the coast of Cilacap Regency, Central Java, Journal of Oceanography, 1(2), 139-148.

G. V., Goswam, S., Samal, R.N., \& Choudhurya, S.B. (2019). Monitoring of Chilika Lake mouth dynamics and quantifying rate of shoreline change using $30 \mathrm{~m}$ multi-temporal Landsat data, Data in Brief, 22, 595-600. doi: https://doi.org/10.1016/j. dib.2018.12.082.

Guariglia, A., Buonamassa, A., Losurdo, A., Saladino, R., Trivigno, M.L., Zaccagnino, A., \& Colangelo, A. (2006). A multisource approach for coastline 
mapping and identification of shoreline changes, Annals of geophysics, 49(1).

Gibson, G.R. (2006). An Analysis of Shoreline Change at Little Lagoon, Alabama. Virginia Polytechnic Inst And State Univ Blacksburg Dept Of Geography.

Gustiantini, L., \& Ilahude, D. (2016, in Indonesia). Bentic Foraminifera in Sediment as an Indicator of Environmental Conditions of Coral Reefs in the Waters of Big Pine Island and Small Pine Island Karimunjawa Islands, Central Java, Jurnal Geologi Kelautan, 10(1), 35-38.

Hartati, R., Ambariyanto, A., \& Dian, R. (2005, in Indonesia). Identifikasi Sand Dollar dan Karakteristik Habitatnya di Pulau Cemara Besar, Kepulauan Karimunjawa Jepara, ILMU KELAUTAN: Indonesian Journal of Marine Sciences, 10(1), 1-10.

Hidayat, J.J., Yusuf, M., \& Indrayanti, E. (2013, in Indonesia). Wave propagation dynamics using the CMS-Wave model on Parang Island, Karimunjawa Islands, Journal of Oceanography, 2(3), 255-264.

Hidayat, N. (2012, in Indonesia). Hydro-Oceanographic Study for detection of physical processes on the coast, Smartek. Tadulako University, 3(2).

Hutabarat, S., \& Evans, S.M. (1985, in Indonesia). Introduction to Oceanography. Penerbit Universitas Indonesia (UI-Press).

Ijima, T., \& Tang, F.L.W. (1967). Numerical calculation of wind waves in shallow water', in Coastal Engineering 1966, pp. 38-49.

Miller, H.M., Sexton, N.R., Koontz, L., Loomis, J., Koontz, S.R., \& Hermans C. (2011). The users, uses, and value of Landsat and other moderateresolution satellite imagery in the United StatesExecutive report. US Department of the Interior, Geological Survey.

Ozturk, D., \& Sesli, F.A. (2015). Shoreline change analysis of the Kizilirmak Lagoon Series. Ocean \& Coastal Management. Elsevier, 118, 290-308.

Resio, D.T., Bratos, S.M., \& Thompson, E.F. (2003). Meteorology and Wave Climate, Chapter II-2, Coastal Engineering Manual. US Army Corps of Engineers, Washington DC, p. 72.

Salmon, C., Duvat, V.K.E., \& Laurent, V. (2019). Human- and climate-driven shoreline changes on a remote mountainous tropical Pacific Island: Tubuai, French Polynesia. Anthropocene, 25, 100191. doi: https://doi.org/10.1016/j. ancene.2019.100191.

Siswanto, A.D., Pratikto, W.A., \& Suntoyo, S. (2012, in Indonesia). Coastline Stability Analysis in Bangkalan Regency, ILMU KELAUTAN: Indonesian Journal of Marine Sciences, 15(4), 221-230.

Triatmodjo, B. (1999). Coastal engineering, Beta Offset, Yogyakarta, 397.

Umardiono, A. (2011). Development of the Karimunjawa Islands Marine National Park Tourism Object. Surabaya: Universitas Airlangga.

Van, T.T., \& Trinh, T. B. (2009). Application of remote sensing for shoreline change detection in Cuu Long estuary. VNU. 
Shoreline Change Dynamics ...... In Cemara Besar Island (Ramdhan, M., et al.) 